Article

\title{
Enhanced Carbofuran Degradation Using Immobilized and Free Cells of Enterobacter sp. Isolated from Soil
}

\author{
Mohammed Umar Mustapha ${ }^{1}$, Normala Halimoon ${ }^{2, *}$, Wan Lutfi Wan Johari ${ }^{2}$ and \\ Mohd. Yunus Abd Shukor ${ }^{3}$ \\ 1 Desert Research Monitoring and Control Centre, Yobe State University, Damaturu P.M.B 1144, Nigeria; \\ umardrc@gmail.com \\ 2 Department of Environment, Faculty of Forestry and Environment, Universiti Putra Malaysia, UPM Serdang, \\ Selangor 43400, Malaysia; wanlutfi@upm.edu.my \\ 3 Department of Biochemistry, Faculty of Biotechnology and Biomolecular Sciences, Universiti Putra Malaysia, \\ UPM Serdang, Selangor 43400, Malaysia; mohdyunus@upm.edu.my \\ * Correspondence: mala_upm@upm.edu.my
}

Received: 21 April 2020; Accepted: 21 May 2020; Published: 16 June 2020

\begin{abstract}
Extensive use of carbofuran insecticide harms the environment and human health. Carbofuran is an endocrine disruptor and has the highest acute toxicity to humans than all groups of carbamate pesticides used. Carbofuran is highly mobile in soil and soluble in water with a lengthy half-life (50 days). Therefore, it has the potential to contaminate groundwater and nearby water bodies after rainfall events. A bacterial strain $\mathrm{BRC} 05$ was isolated from agricultural soil characterized and presumptively identified as Enterobacter sp. The strain was immobilized using gellan gum as an entrapment material. The effect of different heavy metals and the ability of the immobilized cells to degrade carbofuran were compared with their free cell counterparts. The results showed a significant increase in the degradation of carbofuran by immobilized cells compared with freely suspended cells. Carbofuran was completely degraded within $9 \mathrm{~h}$ by immobilized cells at $50 \mathrm{mg} / \mathrm{L}$, while it took $12 \mathrm{~h}$ for free cells to degrade carbofuran at the same concentration. Besides, the immobilized cells completely degraded carbofuran within $38 \mathrm{~h}$ at $100 \mathrm{mg} / \mathrm{L}$. On the other hand, free cells degraded the compound in $68 \mathrm{~h}$. The viability of the freely suspended cell and degradation efficiency was inhibited at a concentration greater than $100 \mathrm{mg} / \mathrm{L}$. Whereas, the immobilized cells almost completely degraded carbofuran at $100 \mathrm{mg} / \mathrm{L}$. At $250 \mathrm{mg} / \mathrm{L}$ concentration, the rate of degradation decreased significantly in free cells. The immobilized cells could also be reused for about nine cycles without losing their degradation activity. Hence, the gellan gum-immobilized cells of Enterobacter sp. could be potentially used in the bioremediation of carbofuran in contaminated soil.
\end{abstract}

Keywords: biodegradation; carbofuran; immobilization; reusability

\section{Introduction}

Pesticide use in agriculture can cause undesirable effects on humans and the natural environment, and different types of toxic organic compounds are being released accidentally or intentionally into the environment [1]. Pesticides are introduced frequently in large volumes via different means [2]. Carbofuran is among the most frequently used insecticides and has been broadly used for the control of insects that destroy crops, such as, tomatoes, cabbages, rice, strawberries, and many other crops. Almost all pesticides belonging to carbamates are synthetic and are widely used all over the globe due to their broad specificity against several pest's organisms [3]. Though pesticides have been developed with the concept of the target organism, however, non-target organisms are often affected badly by their 
application [4]. Carbofuran is a strong inhibitor of acetyl-cholinesterase and has great toxicity, causing health-related disorders [5]. Though carbofuran is chemically unstable as a result of easy hydrolysis in the environment, carbofuran residues are mostly discovered in groundwater because of its extensive use and high mobility in soils [6]. Therefore, their removal from the environment is essential $[7,8]$. To reduce the environmental and public health risks associated with carbofuran use, it is crucial to develop rapid and effective approaches to remove the compound or reduce their concentrations from the environment [1,9].

Conventional approaches for mitigating the impact of pesticide contamination are less-effective and costly [10]. Among the several techniques available are the biological method, which is based on the catabolic activity of pesticide-degrading bacteria, which seems to be the most promising and effective strategy. Recently, immobilization methods have received a great deal of attention from stakeholders [11]. Cell immobilization is an effective biological technique for the removal of pollutants due to improved operational immobility, higher biomass loading, and enriched biodegradation rates [12]. Degradation of pesticides, such as carbofuran, using free cells has been a challenge due to some limitations in their application for bioremediation, which includes cell separation, substrate inhibition, and difficulty in isolating a strain that can withstand high concentration of carbofuran and possible degradation within a shortest possible time. Therefore, to overcome these challenges, immobilized cell technology can be applied for the long-term stabilization of different pollutant-degrading microbes [13-15]. One of the most important aspects of bioremediation is maintaining high biomass of bacterial populations and increase the survival and retention of the bioremediation agents in the polluted areas. Immobilized cells have the possibility of retaining a high cell density, the prevention of cell washout, even at high dilution rates, as well as repeated use of cells, and better protection of cells from harsh environments, which make it have significant benefits over free cells. It has been reported that immobilized cells are much more tolerant of perturbations in the reaction environment and less susceptible to toxic substances, making immobilized cell systems particularly attractive for the degradation of toxic compounds like pesticides [16].

Cell immobilization refers to physical detention or localization of viable microbial cells to a certain distinct area of space so as to limit their free movement with simultaneous preservation of their viability and catalytic functions. It involves two processes-physical retention (inclusion membrane and entrapment) and chemical bonding, for instance, biofilm formation [17]. The technique may use the natural capability of microbes to form biofilms on the surface of various materials, which is commonly observed in the environment. There are five main techniques of immobilization, which are adsorption, binding on a surface (electrostatic or covalent), flocculation (natural or artificial), entrapment, and encapsulation [18]. Several materials are used for immobilization of cells, including inorganic, such as clays, silicates, glass, and ceramics, as well as organic, such as cellulose, starch, dextran, agarose, alginate, chitin, collagen, keratin, etc. Immobilization significantly reduces the costs of bioremediation processes and also increases their efficiency. The immobilized cells could be reused over and over, hence decreasing the costly processes of recycling and recovery of cells $[19,20]$. Moreover, the immobilized microbial cells may offer many benefits, such as high mechanical strength, high resistance to toxic chemicals, and high metabolic activity, due to high biomass concentrations and dispersal blockades within the biofilm, as well as stopping wash out of cells from the beads [21]. The study aimed at isolating bacteria capable of degrading carbofuran and immobilizing the bacterium on a natural carrier (gellan gum) to produce a metabolically active, biological agent for the biodegradation of carbofuran in polluted soil.

\section{Results and Discussions}

\subsection{Isolation and Identification}

The carbofuran-degrading bacterium was isolated using enrichment methods. The strain BRC05 was isolated in soil and tested for its ability to degrade carbofuran by using the compound as a source 
of nitrogen or carbon. The bacterium was motile, rod-shaped, and a Gram-negative strain with the flagellum. Based on the biochemistry performed, the isolate was citrate-positive, catalase-negative, oxidase, and non-spore forming bacteria. 16S rRNA gene sequence analysis was done to compare with related sequences available in the NCBI GenBank, and the strain BRC05 showed high similarity with the genus Enterobacter sp. The sequence of the amplified DNA showed a high similarity of $97 \%$ with the genius Enterobacter sp., and the top ten Blast search of closely related species together with their accession numbers are presented in Table 1.

Table 1. The similarity of the isolate BRC05 16S rRNA gene sequence of the top ten Blast search result together with the 16S rRNA gene sequence of bacterium BRC05 and closely related species from the NCBI database.

\begin{tabular}{|c|c|c|c|c|c|c|}
\hline \multirow[t]{2}{*}{ Description } & Max & Total & Query & E & Per. & \multirow[t]{2}{*}{ Accession } \\
\hline & Score & Score & Cover & Value & Ident & \\
\hline Enterobacter cloacae strain PSMK $16 \mathrm{~S}$ ribosomal RNA gene, partial sequence & 1537 & 2796 & $99 \%$ & 0 & $99.64 \%$ & MK641315.1 \\
\hline Enterobacter cloacae strain JE3 16S ribosomal RNA gene, partial sequence & 1537 & 2709 & $96 \%$ & 0 & $99.64 \%$ & KY942149.1 \\
\hline Enterobacter cloacae R11 DNA, complete genome & 1535 & 22072 & $99 \%$ & 0 & $99.53 \%$ & CP019839.1 \\
\hline Enterobacter sp. pp9c chromosome, complete genome & 1535 & 22253 & $99 \%$ & 0 & $99.53 \%$ & GQ360072.1 \\
\hline Enterobacter cloacae strain HK196 chromosome, complete genome & 1535 & 22007 & $99 \%$ & 0 & $99.53 \%$ & CP17087.1 \\
\hline Enterobacter cloacae strain DF3 chromosome complete genome & 1535 & 22072 & $99 \%$ & 0 & $99.53 \%$ & MG774409.1 \\
\hline Enterobacter sp. PXG11 chromosome, complete genome & 1535 & 22138 & $99 \%$ & 0 & $99.53 \%$ & JQ396391.1 \\
\hline Enterobacter cloacae strain DMKU-RP206 16S ribosomal RNA gene, partial sequence & 1535 & 2788 & $99 \%$ & 0 & $99.53 \%$ & MF125281.1 \\
\hline Enterobacter cloacae strain MR1 chromosome, complete genome & 1535 & 22166 & $99 \%$ & 0 & $99.53 \%$ & KC999878.1 \\
\hline Enterobacter sp. Z-16 chromosome, complete genome & 1535 & 21991 & $99 \%$ & 0 & $99.53 \%$ & DQ363438.1 \\
\hline
\end{tabular}

Max score is highest alignment score calculated from the sum of the rewards for matched nucleotides, Total score is the sum of alignment scores of all segments from the same subject sequence E-Value: the number of alignments expected by chance with the calculated score or better. The expect value is the default sorting metric; for significant alignments the E value should be very close to zero. Ident: is the highest percent identity for a set of aligned segments to the same subject sequence.

\subsection{Degradation Studies for Enterobacter sp. Strain BRC05 by Comparison between Immobilized Cell and Freely-Suspended Cell}

The experiment showed the degradation of carbofuran at different time intervals and concentration by free cells and immobilized cells of Enterobacter sp. strain BRC05. The immobilized and free bacteria at optimized conditions were tested for their carbofuran-degrading activity, and the microbial growth was inhibited at higher concentrations of carbofuran. At different initial carbofuran concentrations, both free and immobilized bacteria demonstrated similar carbofuran-degrading activity, and carbofuran was degraded completely in the first few hours of incubation. As the concentration of carbofuran increased, the immobilized cells exhibited a faster degrading ability than the free cells.

Figure 1a-e displays the results for the degradation of carbofuran by free and immobilized cells at different times and concentrations. As a negative control, empty beads without bacteria were used at the same carbofuran concentrations. There was no degradation observed in the negative control beads at the end of the experiment. At $50 \mathrm{mg} / \mathrm{L}$ carbofuran concentration (Figure 1a), the immobilized cells were able to degrade carbofuran completely within $9 \mathrm{~h}$ when compared to the free cell, which took $12 \mathrm{~h}$ to degrade carbofuran. With the increased concentration of carbofuran up to $250 \mathrm{mg} / \mathrm{L}$, the rate of degradation decreased in free cells. The immobilized cells completely degraded carbofuran within 15 and $38 \mathrm{~h}$ at 50-100 mg/L. On the other hand, free cells degraded the compound in 14 to $68 \mathrm{~h}$ at concentrations 50 and $100 \mathrm{mg} / \mathrm{L}$, respectively (Figure $1 \mathrm{~b}, \mathrm{c}$ ). The biodegradation activity of carbofuran by immobilized and free cells at concentrations of 150 and $200 \mathrm{mg} / \mathrm{L}$ was somewhat inhibited (Figure 1d,e). 


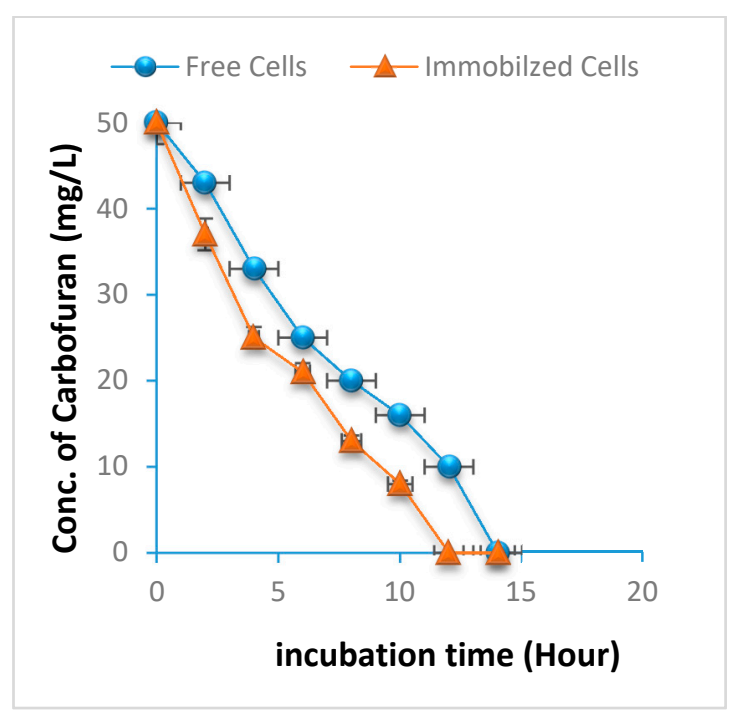

(a)

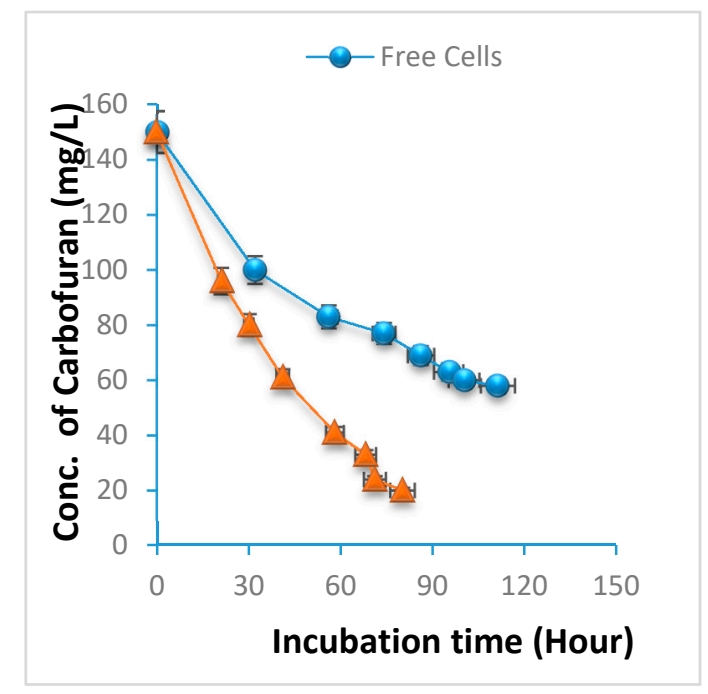

(c)

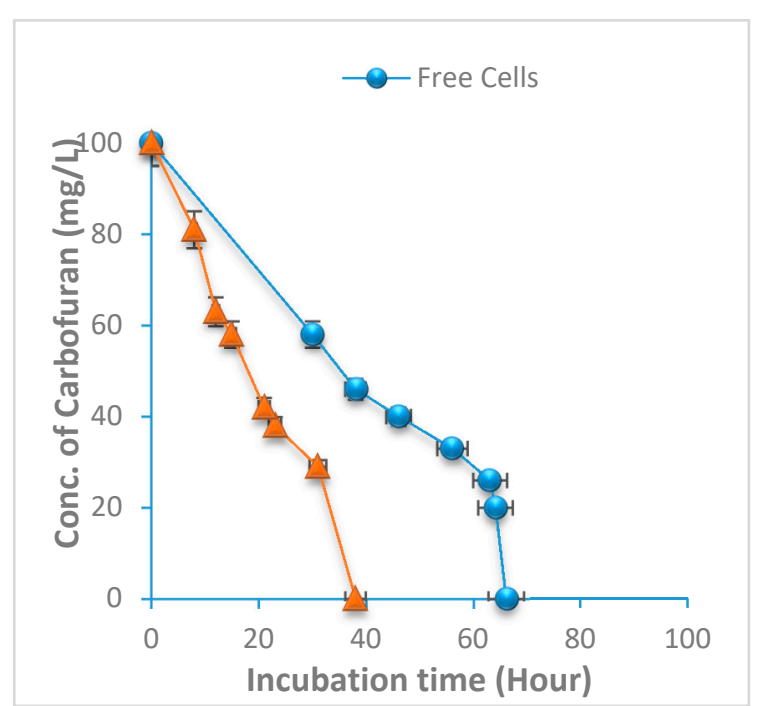

(b)

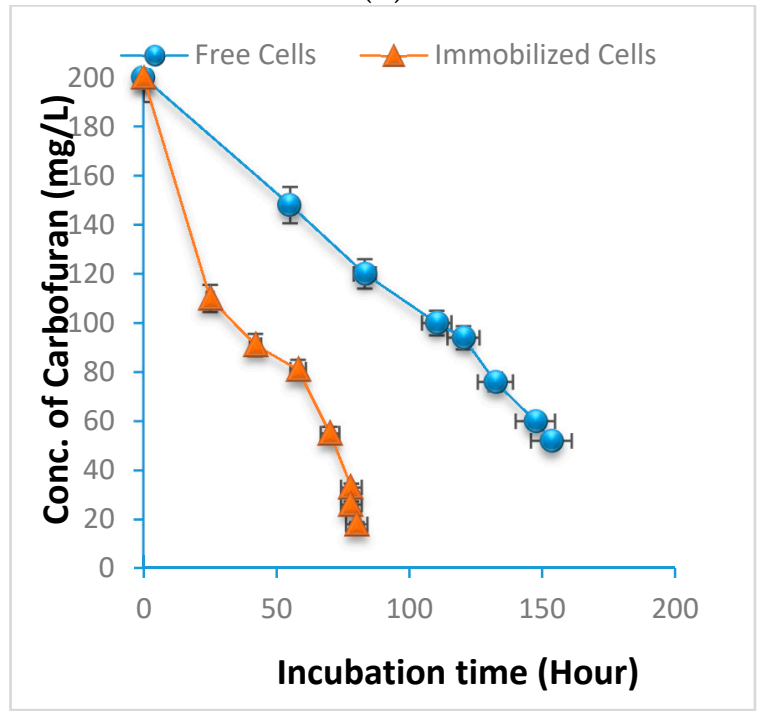

(d)

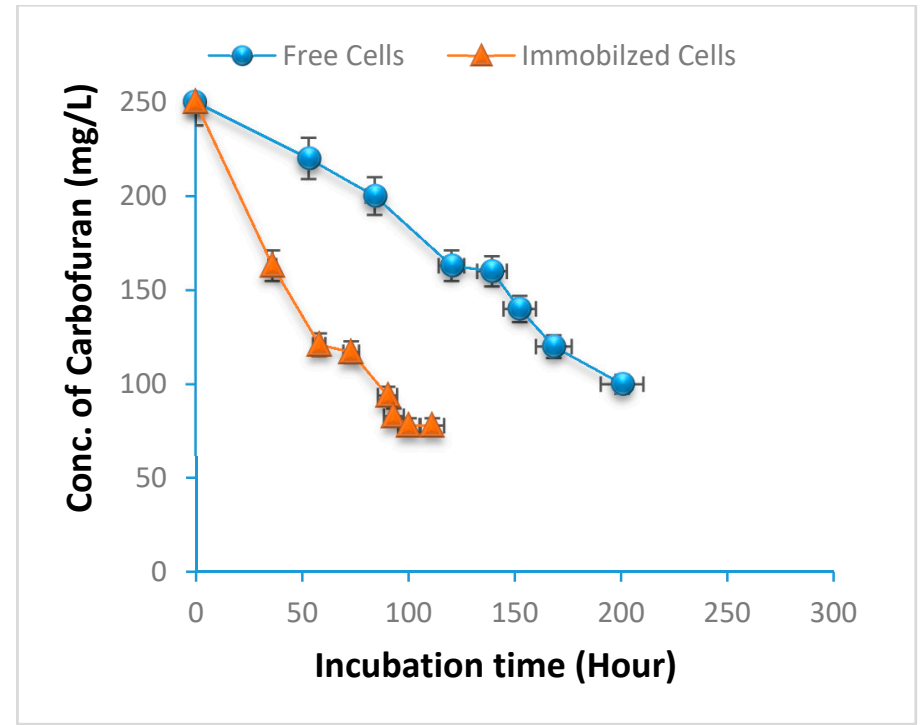

(e)

Figure 1. Effect of different concentrations of carbofuran on free and immobilized Enterobacter sp. cells on the degradation of carbofuran over a long period of incubation. The concentrations of carbofuran selected were (a) $50 \mathrm{mg} / \mathrm{L}$, (b) $100 \mathrm{mg} / \mathrm{L}$, (c) $150 \mathrm{mg} / \mathrm{L}$, (d) $200 \mathrm{mg} / \mathrm{L}$, and (e) $250 \mathrm{mg} / \mathrm{L}$. Data represent mean $\pm S D, n=3$. 
The isolate was incapable of degrading carbofuran completely at these levels, while, at $250 \mathrm{mg} / \mathrm{L}$, the degradation of carbofuran was very minimum for free cells after 160 and $190 \mathrm{~h}$, respectively. Higher concentrations of gellan gum or cell loadings or larger bead sizes could create diffusional limitations, such as decreased oxygen availability to the immobilized cells, which might lead to a reduction in some aspects of cellular activity and reduced degradation capacity. This limitation could be overcome by using smaller beads size or more porous polymer like gellan gum, as well as an appropriate number of beads. Previous studies have shown that immobilization of cells can significantly increase the removal efficiency of different pesticides compared with free cells. Immobilized Burkholderia cepacia PCL3 degrades carbofuran at higher concentrations [9]. In another study by Plangklang et al. [16], the strain PCL3 in the free-cell form was able to degrade carbofuran phenol at low concentrations and was inhibited at a high concentration, while the immobilized cells of PCL3 were not inhibited even at higher concentrations of carbofuran phenol.

Similar results were reported by Fareed et al. [15], where immobilized cells of Enterobacter cloacae strain TA7 effectively degraded in $N$-methyl carbamates pesticides more rapidly than freely suspended cells counterpart. At $300 \mathrm{mg} / \mathrm{L}$ of phenol, the freely suspended cells showed a lower specific degradation rate, whereas, the immobilized cells demonstrated a higher phenol degradation rate [22]. Pseudomonas putida strain (CCRC14365) was able to degrade $600 \mathrm{mg} / \mathrm{L}$ of phenolic compounds in the free cells system and up to $1000 \mathrm{mg} / \mathrm{L}$ with immobilized cells [23]. This further justified that immobilized cells were efficient over time in carbofuran-degrading activities than freely-suspended cells, as shown in the present study. In another study, enhanced degradation of carbofuran phenol was achieved by the immobilized cells of Klebsiella pneumoniae as compared with its free cells counterpart [21]. Gellan gum immobilized Acinetobacter sp. completely degraded phenol within 108, 216, and $240 \mathrm{~h}$ at 1100 , 1500 , and $1900 \mathrm{mg} / \mathrm{L}$ concentration of phenol, while the freely suspended cells took $240 \mathrm{~h}$ to completely degrade phenol at $1100 \mathrm{mg} / \mathrm{L}$ as the phenol-degrading activity of the free bacteria was inhibited at higher concentrations of the phenolic compound [24].

In another study, phenol degradation by free and immobilized cells of Bacillus cereus was similar at lower concentrations of 100 to $1000 \mathrm{mg} / \mathrm{L}$. While almost $50 \%$ of $2000 \mathrm{mg} / \mathrm{L}$ was degraded within 26 and 36 days. This showed the enhanced degradation efficiency of the immobilized cells, which was higher at higher concentrations than free cells [25]. Besides, Thatheyus et al. [26] reported enhanced degradation of acrylamide by immobilized cells of Pseudomonas aeruginosa, where degradation started within $24 \mathrm{~h}$ of incubation, whereas it took the free cells $48 \mathrm{~h}$ to show degradation. The higher degradation rate of crude oil was also achieved by using immobilized bacterial consortium [27,28]. Additionally, an immobilized cell of Pseudomonas putida was reported to have degraded higher concentrations of chlorpyrifos as compared to its free cells [29].

\subsection{Effect of Heavy Metals on the Degradation of Carbofuran by Enterobacter sp. Strain BRC05}

The effect of heavy metals on the degradation of carbofuran, by immobilized and free cells, was checked by culturing in the MSM medium at $37^{\circ} \mathrm{C}$ in the presence of different heavy metals. One part per million $(1 \mathrm{mg} / \mathrm{L})$ of heavy metals, such as copper $(\mathrm{Cu})$, chromium $(\mathrm{Cr})$, mercury $(\mathrm{Hg})$, cadmium $(\mathrm{Cd})$, arsenic $(\mathrm{As})$, zinc $(\mathrm{Zn})$, lead $(\mathrm{Pb})$, and nickel $(\mathrm{Ni})$, were tested, and the effects of the metals between free and immobilized cells were compared, as shown in Figure 2. A control experiment was prepared without the addition of heavy metals into the medium. The degradation was strongly inhibited by mercury and copper, at $1 \mathrm{mg} / \mathrm{L}$, while the inhibitory effect of lead and chromium at the same concentration was negligible. In contrast, cadmium did not affect the degradation at the concentration used. The degradation of carbofuran did not take place in the control flask by free cells ( $p \geq 0.05$ ). In immobilized cells, $\mathrm{Hg}$ and $\mathrm{Cu}$ inhibited carbofuran-degrading activities; however, the degradation was higher compared with the free cells $(p \leq 0.05)$. Hence, different concentrations of $\mathrm{Hg}$ and $\mathrm{Cu}$ were used for the degradation of carbofuran. The degradation was higher in immobilized than the free cells at the same concentration. The degradation of carbofuran was far lesser in free cells compared to the performance of the immobilized cells. Some heavy metals are essential to 
living cells, while others may be harmful to living cells even at reduced concentrations. Some heavy metals are readily metabolized and assist in metabolic activities, such as detoxification, assimilation, and methylation. Heavy metals affect the degradation of the pesticides in soil by influencing the microbial actions in the environment [30]. The presence of heavy metals in polluted areas is one of the main limiting factors for bioremediation because several organisms might not tolerate high concentrations of metals; therefore, their ability to degrade pollutants might reduce due to the effect of metals [31], and consequently, the need to assess the effect of heavy metals on the biodegradation of organic compounds. Many researchers reported the effects of heavy metal on the microbial growth; yet, there is very limited information concerning their effects on the degradation of pesticides [22,32].

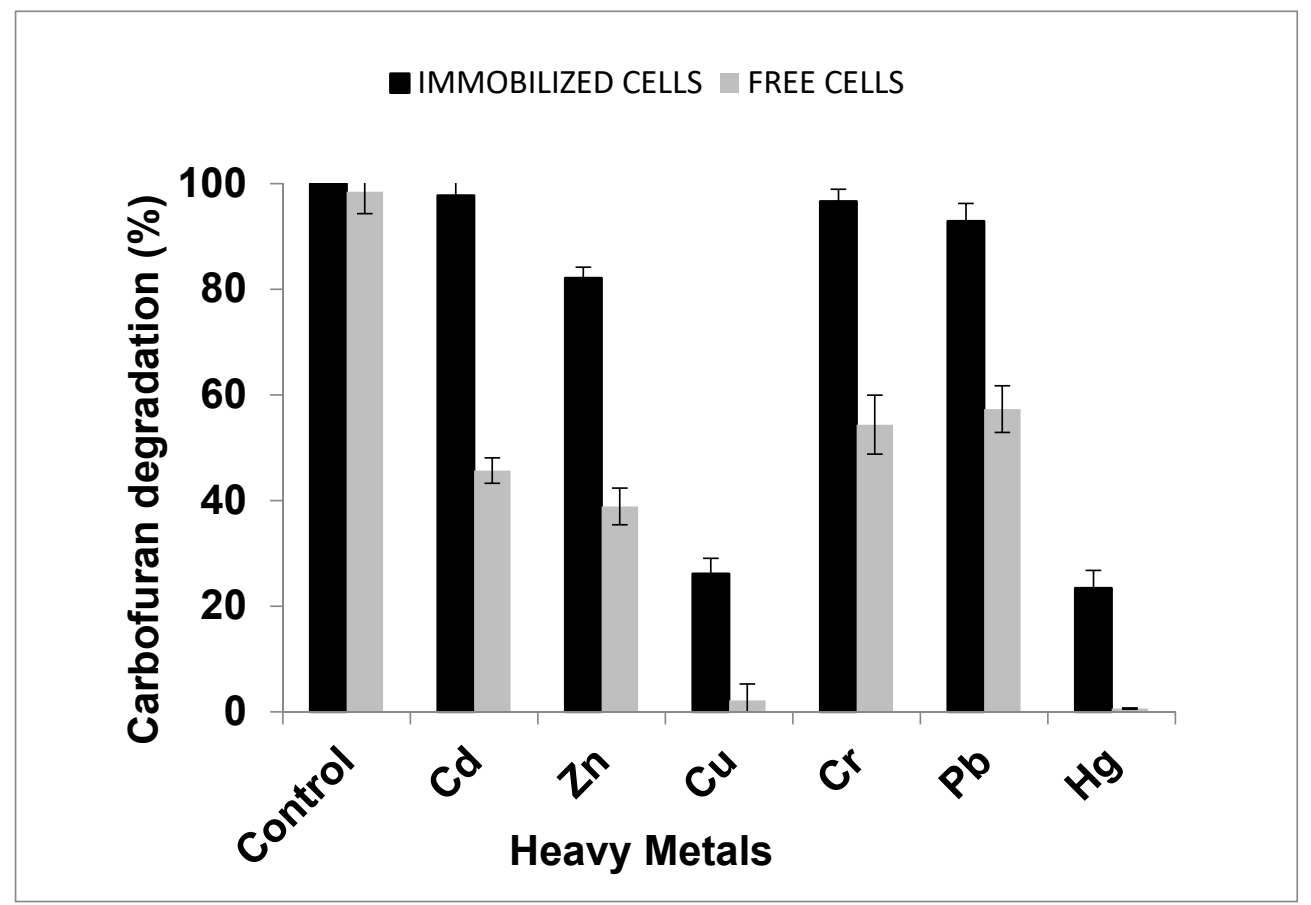

Figure 2. The effect of different heavy metals on the degradation of carbofuran by the immobilized and free cells of Enterobacter sp. Data represent mean $\pm \mathrm{STDEV}, n=3$.

The result obtained agreed with the work of Hong et al. [33] in which the addition of lead $(\mathrm{Pb})$ had an insignificant inhibitory effect on the degradation of dibenzofuran, and mercury (Hg) highly inhibited the degradation. The free cells were inhibited easily by the heavy metals, hence reducing the rate of degradation through distressing the cells' membrane structure, whereas the immobilized cells were protected by the beads gel and less affected by the heavy metal, therefore, decreasing the chance of being inhibited by the heavy metals [3,33]. The existence of heavy metals at the polluted site is frequently the main hindering factor for effective bioremediation as the microbial population could not withstand a high concentration of heavy metals, and thus, their ability to degrade the target compounds may decrease [11].

\subsection{Effect of Mercury $(\mathrm{Hg})$ on the Degradation of Carbofuran by Immobilized Cells of Enterobacter sp.}

Mercury $(\mathrm{Hg})$ belongs to one of the noxious non-radioactive heavy metals, which is widely dispersed in nature [34]. Mercury is a persistent and bio-accumulative compound. Many polluted sites are co-contaminated with organic and metal pollutants. Data from both aerobic and anaerobic systems show that biodegradation of the organic compound may be reduced by metal toxicity [31,35-37]. Widespread use of pesticides and fertilizers may also have led to the presence of heavy metals in soil. The effect of mercury on the degradation of carbofuran was determined using 0.1 to $1 \mathrm{mg} / \mathrm{L}$ concentration. The outcomes revealed that concentrations of mercury from 0 to $1 \mathrm{mg} / \mathrm{L} \mathrm{had}$ affected 
the degradation performance of carbofuran, as shown in Figure 3. Increasing the concentration of mercury to $0.5 \mathrm{mg} / \mathrm{L}$ caused a significant reduction in the degradation of carbofuran by the immobilized cells, which could be classified as detrimental as it influenced the degradation of the pesticides in soil by affecting the activity of microorganisms. An analysis of variance showed no significant difference $(p \geq 0.05)$ for immobilized cells between $0.1,0.2,0.3$, and 0.4 . It has been reported that metals appear to affect the biodegradation of organic compounds by affecting both the physiology and ecology of organic compound-degrading microorganisms [38]. Reports by Radjendirane et al. [37] showed that mercury could hinder hydroxylases activity like aryl 2,4-dichlorophenol hydroxylase and 3-hydroxybenzoate-6-hydroxylase. In another study by Ibrahim et al. [35], the authors found that concentrations of mercury from 0.1 to $1 \mathrm{mg} / \mathrm{L}$ affected the degradation of caffeine by Leifsonia sp. isolated from soil. The degradation of dibenzofuran by Sphingomonas wittichii RW1 was strongly inhibited by mercury at $1 \mathrm{mg} / \mathrm{L}$ [33].

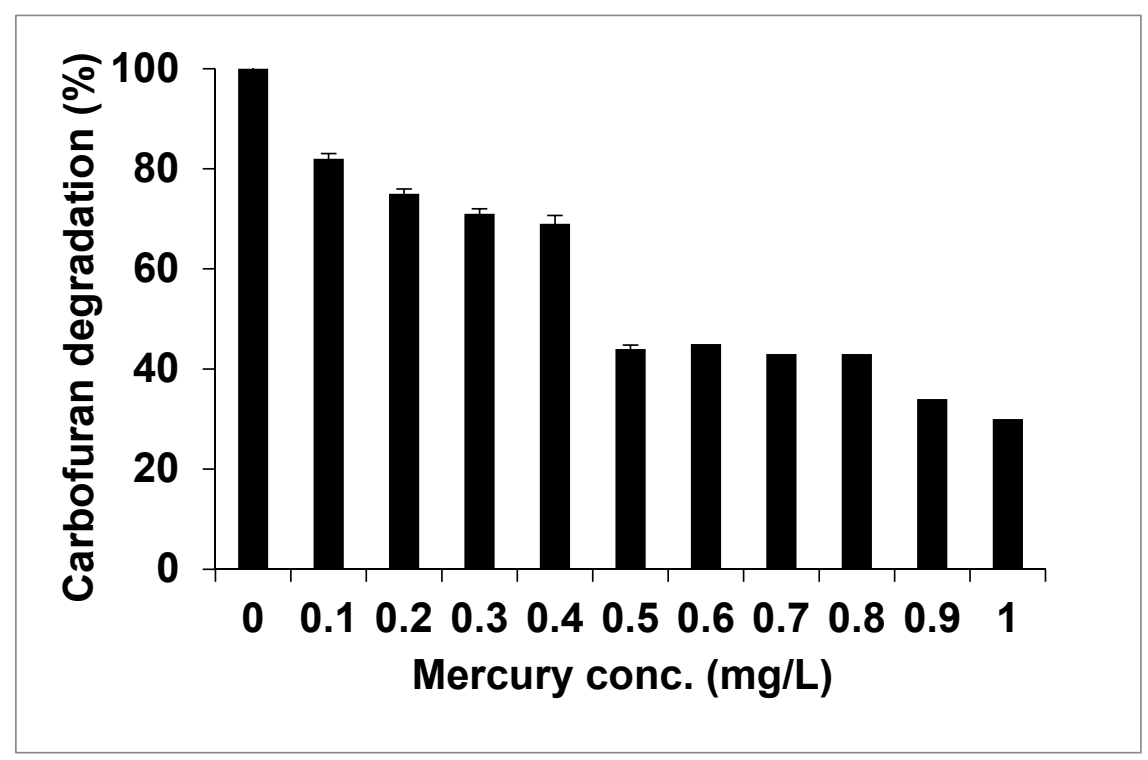

Figure 3. The effect of concentrations of mercury on the degradation of carbofuran by the immobilized cells of Enterobacter sp.

\subsection{Reusability of Gellan Gum Beads}

The breakdown of the beads was observed when the beads began to disintegrate into semicircular parts, while some of the beads were scratched before overflowing. This might be a result of the mechanical force (shaking) that had been applied in the course of incubation using a shaker at $150 \mathrm{rpm}$. The bursting might have also triggered by the excessive growth of the entrapped cells, which could ultimately break the bead surface and cause leakage of cells. Figure 4 displays the results for the reusability of immobilized Enterobacter sp. strain BRC05 for degrading $100 \mathrm{mg} / \mathrm{L}$ carbofuran. Based on the result obtained, carbofuran was completely degraded at the first cycle, which was $24 \mathrm{~h}$, and the carbofuran-degrading ability disappeared after reusing the immobilized cells for nine cycles. The result pointed out that immobilized bacterial cells could be reused for up to nine sequential complete degradation cycles without any decline in carbofuran-degrading ability [39]. 


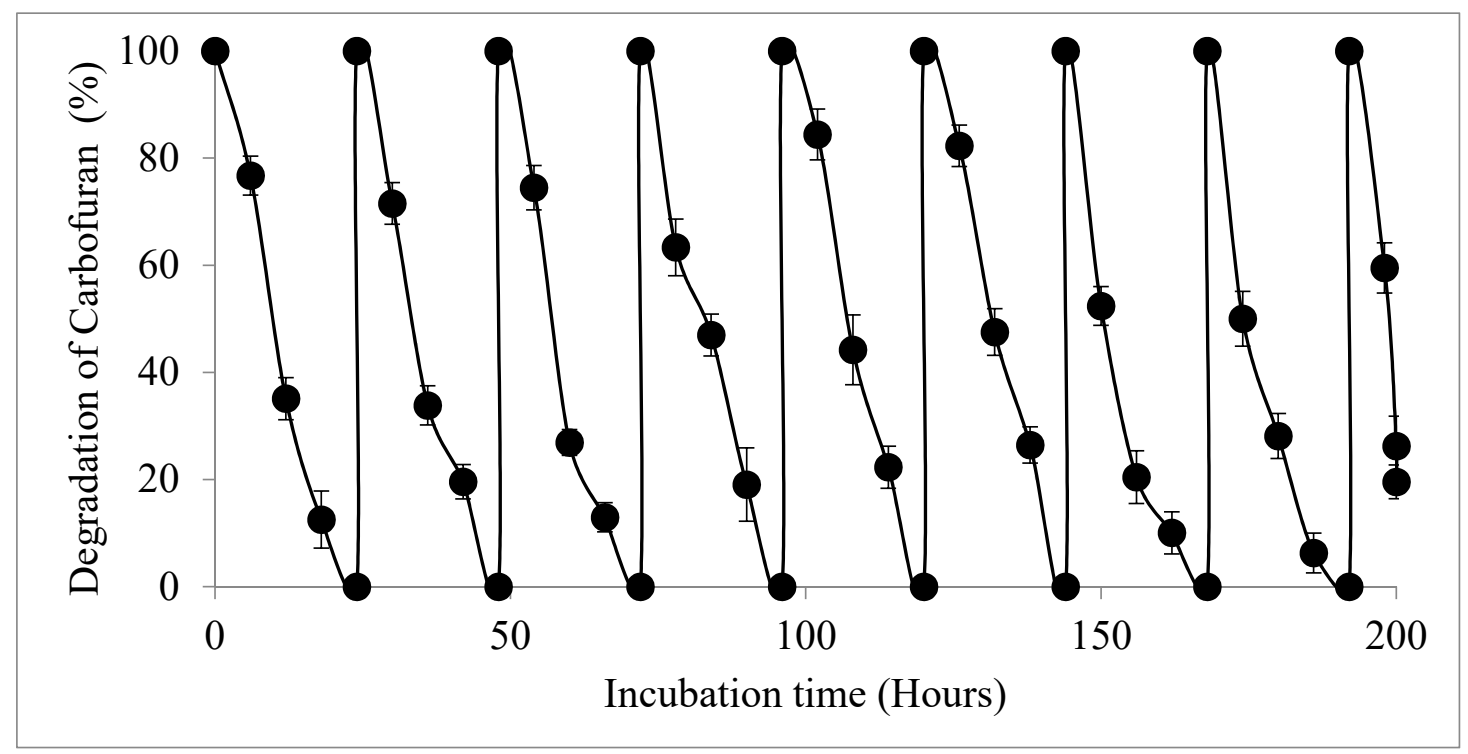

Figure 4. Repeated batch cycles of immobilized Enterobacter sp. Data is displayed for repeated usage only, and each cycle involved $24 \mathrm{~h}$ cycle. Data represent mean \pm SD.

Repeated application of remediation agent in the process of biodegradation is one of the benefits of the immobilized cells [24,40]. Hence, it was essential to find out how many times the immobilized cells produced in this study could be reused. The reusability experiment for immobilized bacterial cells was performed to study the viability of the entrapped cells in the degradation of carbofuran after one complete cycle. Manohar et al. [41] reported that beads containing entrapped Pseudomonas species were capable of degrading naphthalene 18 times in a cycle of 2-3 days before they lost their degrading activity. Acinetobacter sp. was used repeatedly up to five times. Ahmad et al. [24] revealed that the cells of immobilized Acinetobacter sp. were used for up to 47 successive cycles. The immobilized Acinetobacter sp. strain XA05 and Sphingomonas sp. were also recycled for up to 20 times reusability [42]. The reusability of beads (repeated batch) is one of the benefits of bacterial cell immobilization by which immobilized beads can be used for a prolonged period [43]. The reusability of beads means that the cells can survive, and metabolic activity can be preserved for prolonged periods. The reusability assessment was conducted on the immobilized Enterobacter sp. strain BRC05 cells in gellan gum to determine repeated usage of the beads for the degradation of carbofuran, as shown in Figure 5.
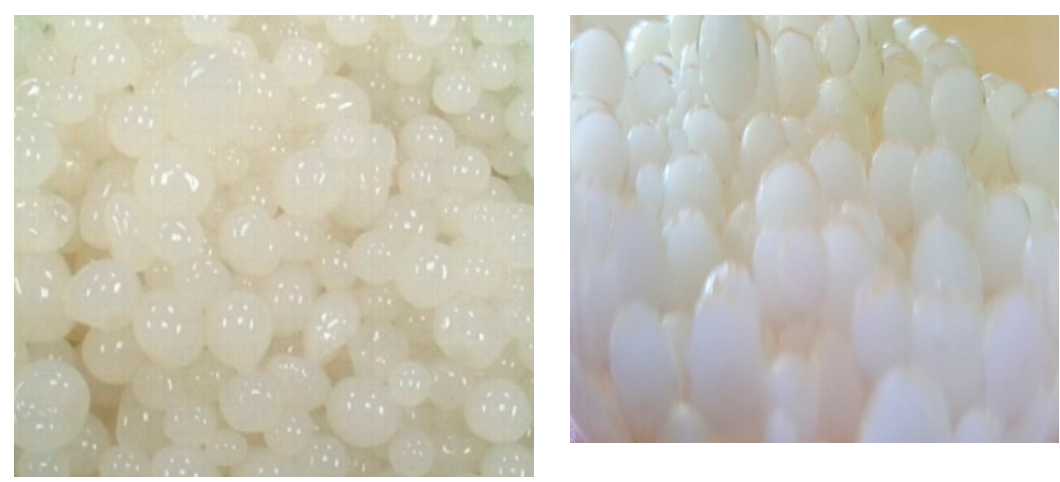

Figure 5. Gellan gum microbeads of Enterobacter sp. strain BRC05 before and after 24-h cycle degradation.

Massalha et al. [44] reported that an immobilized phenol-degrading microbe was recycled for three repeated cycles. There is inadequate literature on more than 50 cycles of reusability. An immobilized cell of Klebsiella sp. strain ATCC13883T could be recycled for more than 28 cycles in alginate-bentonite clay-PAC without losing any degradation capacity [21]. Immobilized Burkholderia cepacia PCL3 could 
be reused three times and still maintain its ability to degrade carbofuran. Based on the results obtained, it could be concluded that gellan gum immobilization had increased cell survival and metabolic activity in the bioremediation system.

\section{Material and Methods}

\subsection{Chemicals and Medium}

Analytical grade insecticide carbofuran (Furadan) 2,3-dihydro-2,2-dimethyl-7-benzofuranyl-methyl carbamate (99\% purity) was purchased from Sigma-Aldrich, Missouri, USA. Minimal salt medium (MSM) and Luria Bertani (LB) contained the following compositions (in g/L): mineral agar $20 \mathrm{~g}$, yeast extract $5 \mathrm{~g}$, tryptone $10 \mathrm{~g}, \mathrm{NaCl} 10 \mathrm{~g}$, and distilled water $1000 \mathrm{~mL}$. Then, $0.1 \mathrm{~g} / \mathrm{L}$ of cycloheximide was added to all solid media to quash the growth of other microbes like fungus [45].

\subsection{Analytical Technique}

The standard solutions of carbofuran were prepared in acetonitrile to the final concentrations. The degradation of carbofuran was checked using HPLC (Agilent Technologies 1200 series, Waldbronn, Germany) using a column C18 ZORBAX ${ }^{\circledR} 25 \mathrm{~cm} \times 4.6 \mathrm{~mm}$, fitted with a C18 silica reverse-phase guard column and equipped with a UV detector [46]. Carbofuran was detected at $254 \mathrm{~nm}$ wavelength at a run time of $5 \mathrm{~min}$ as well as the flow rate of $1 \mathrm{~mL} / \mathrm{min}$ using HPLC grade acetonitrile (70\%) and degassed water $(30 \%)$ as the mobile phases. A sample amount of $20 \mu \mathrm{L}$ was injected into the machine at an oven temperature of $26^{\circ} \mathrm{C}$. An external standard method was used for calibration. For quality control, the precision of the methods used in this study was established by HPLC injections of the samples in triplicate. The accuracy of the method was also ensured by running blank solvents and standards (every six injections) between the injections [6,47].

\subsection{Sampling}

Soil samples were collected from the agricultural soil with a history of pesticide application from vegetable plantation farms, in peninsular Malaysia. Ten composite soil samples $(8-15 \mathrm{~cm})$ from each sampling station were taken randomly using stainless steel scoop; the soil samples were collected in pre-sterilized bags and instantly sealed. The soil samples were stored at $4{ }^{\circ} \mathrm{C}$ to preserve the biological activity of the soil microorganisms [48].

\subsection{Isolation of Carbofuran-Degrading Bacteria}

Indigenous bacteria were isolated from the soil via enrichment methods. One gram of each soil sample was suspended in $10 \mathrm{~mL}$ of sterile mineral salts medium (MSM) containing an initial $5 \mathrm{mg} / \mathrm{L} \mathrm{of}$ carbofuran as the sole carbon source. The 10-fold serial dilutions of the soil samples were inoculated into 100-mL MSM added with $50 \mathrm{mg} / \mathrm{L}$ carbofuran in the 250-mL flask, and the experiment was done under aseptic conditions in triplicate. A flask containing similar inoculum without the addition of carbofuran served as the control experiment. A $0.2 \mathrm{~mL}$ aliquot of the incubated and serially diluted enriched culture was poured in agar plates containing $50 \mathrm{mg} / \mathrm{L}$ carbofuran and then incubated at $37^{\circ} \mathrm{C}$ for $48 \mathrm{~h}$ [49]. A sterile wire loop was used to pick the bacterial colonies in the plates and then restreaked into LB agar plates and incubated at $32{ }^{\circ} \mathrm{C}$ for two days. Sub-culturing was done every two weeks on carbofuran-containing agar plates until pure colonies were obtained [50]. The isolate was identified using biochemical tests and the $16 \mathrm{~S}$ rRNA gene sequence.

\subsection{Immobilization of Bacterial Strain}

Bacterial cells were entrapped in gellan gum following an earlier described method by Ahmed et al. [24,51]. A culture was grown on a large-scale to obtain enough cells of the strain to be immobilized. The bacterial cells were provided with adequate oxygen through an oxygen pump to increase the aeration for the cells in the flask and speeding the growth of the cells. After 2 days 
of incubation, the culture was then centrifuged at $12,000 \times g$ for $10 \mathrm{~min}$. The pellets obtained were used for cell immobilization experiments using gellan gum. About $0.75 \%(w / v)$ of gellan-gum was firstly added to a $100 \mathrm{~mL}$ distilled water and boiled to about $75^{\circ} \mathrm{C}$ to completely liquefy the gellan gum. Then, $0.06 \%(w / v) \mathrm{CaCl}_{2}$ was added to the solution and slowly chilled to nearly $50{ }^{\circ} \mathrm{C}$ at $\mathrm{pH}$ 7.0. The solution temperature was reduced to approximately $45{ }^{\circ} \mathrm{C}$. Then, the subsequent bacterial pellet was added to the gum mixture while shaken continuously. An amended tip was used for the formation of beads by dropping the gum mixture into a sunflower canola oil containing $0.16 \%$ Span 80 , which served as an emulsifier [22,52]. The equivalently sized beads were then separated from the oil into $500 \mathrm{~mL}$ of $0.2 \%(w / v) \mathrm{CaCl}_{2}$. After two hours, the beads were recurrently rinsed with $0.1 \%(v / v)$ tween 80 solution to get rid of the oil phase from the microbeads. The beads were kept overnight in distilled water at $4{ }^{\circ} \mathrm{C}$ before being harvested by filtration and used for the degradation of carbofuran experiments [22].

\subsection{Comparison of the Biodegradation of Carbofuran by Freely Suspended and Immobilized Cells}

The evaluation of the degradation of carbofuran between immobilized and free cells of the bacterial isolate was made using the same initial biomass concentration for both immobilized and freely suspended cells. The optimum number of beads was used to estimate the number of microbial cells required for the degradation of carbofuran using free cells. Approximately $4 \%$ of the isolate was inoculated in a $100 \mathrm{~mL}$ MSM medium [53]. Concentrations of 50-250 mg/L carbofuran was used for both the immobilized and freely suspended cells. Different carbofuran concentrations were added into $100 \mathrm{~mL}$ of MSM medium, and the immobilized and free cells were added in a separate conical flask and incubated in a rotary shaker at $150 \mathrm{rpm}$ at $37^{\circ} \mathrm{C}$ temperature $[13,21]$. One milliliter of the samples was removed at some intervals of time and tested for the degradation of carbofuran until complete or maximum degradation of carbofuran was achieved. MSM medium without the addition of bacterial culture served as the controls. The experiments were conducted in triplicate [54].

\subsection{Effect of Heavy Metals on the Degradation of Carbofuran by Enterobacter sp. BRC05}

The effect of seven (7) different heavy metals was tested on the biodegradation of carbofuran by Enterobacter sp. Strain BRC05. The heavy metals used included copper $(\mathrm{Cu})$, chromium $(\mathrm{Cr})$, mercury $(\mathrm{Hg})$, cadmium $(\mathrm{Cd})$, arsenic $(\mathrm{As})$, zinc $(\mathrm{Zn})$, lead $(\mathrm{Pb})$, and nickel $(\mathrm{Ni})$ in $1 \mathrm{mg} / \mathrm{L}$ concentrations, which were preferred based on previous data on heavy metal concentrations in the study areas [3]. Thirty-six hours old bacterial culture with an optical density of $0.7-0.8$ was used as inoculum for free cells and immobilized beads. The bacteria (free or immobilized) were inoculated into the MSM medium supplemented with $1 \mathrm{mg} / \mathrm{L}$ of each heavy metal. Medium without the addition of heavy metals was used as control [55]. The culture was incubated using a shaker incubator (150 rpm) at $37^{\circ} \mathrm{C}$. Bacterial growth was measured by taking the $\mathrm{OD}_{600}$ for free cells. The heavy metals that affected the degradation of carbofuran were observed, and the experiments were repeated for immobilized cells, and the incubation period was extended until the maximum degradation of carbofuran had been realized. All experiments were carried out in triplicates.

\subsection{Reusability of Gellen Gum Beads}

In this study, 250 beads were added to $100 \mathrm{~mL}$ of medium supplemented with $100 \mathrm{mg} / \mathrm{L}$ of carbofuran. The cells were then incubated in a shaker at $150 \mathrm{rpm}$ for $24 \mathrm{~h}$, and then the residual carbofuran was measured during this period. After every $24 \mathrm{~h}$ incubation, the medium was thrown out, and the gellan gum beads were carefully washed and rinsed with distilled water before they were placed into a new fresh carbofuran medium. The steps were repeated at $24 \mathrm{~h}$ cycles until a reduction in the ability of the immobilized cells to degrade carbofuran was observed, and the beads started to disintegrate. All experiments were carried out in triplicates [17]. 


\section{Conclusions}

Local soil bacteria were isolated from agricultural farms in Malaysia and identified as Enterobacter species by using 16S rRNA sequencing. The cells of the bacterium were immobilized using gellan gum as an entrapment matrix. The outcome of the analysis showed that both free and immobilized cells of the bacterium were able to degrade carbofuran insecticide. Nevertheless, the performance of the immobilized cells was more efficient compared with the free cell system because the immobilized cells remain viable for longer periods and can withstand higher concentrations of carbofuran. Immobilization using gellan gum is a convenient technique where maximum cells remain viable and can withstand a high concentration of pollutants for a long time. Thus, the study showed the potential of immobilized Enterobacter sp. strain BRC05 in the remediation of soils contaminated with carbofuran. Furthermore, gellan gum is nontoxic to the bacterial cell, and it has low production cost and can be reused. The reusability saves the need for generating new biomass for each use. Moreover, the immobilized cells can be beneficial as a bioremediation agent in carbofuran contaminated sites. Furthermore, there is a need to further purify the carbofuran-degrading enzyme in future studies.

Author Contributions: Conceived and designed experiment by N.H., M.U.M. performed the experiments: Data analysis was done by M.U.M. and Thanks to M.Y.A.S. for a helping hand when we needed it most. W.L.W.J., Contributed reagents/materials/analysis tools: M.U.M. Wrote the manuscript and edited by N.H. All authors have read and agreed to the published version of the manuscript.

Funding: This study was funded by Geran Putra IPS UPM with grant number: UPM/800/3/3/1/GP-IPS/2018/ 9636200), awarded by Universiti Putra Malaysia (UPM).

Conflicts of Interest: The authors declare no conflict of interest.

\section{References}

1. Tien, C.J.; Huang, H.J.; Chen, C.S. Accessing the Carbofuran Degradation Ability of Cultures From Natural River Biofilms in Different Environments. CLEAN Soil Air Water 2017, 45, 1600380. [CrossRef]

2. Rahaman, M.M.; Islam, K.S.; Jahan, M. Rice Farmers' Knowledge of the Risks of Pesticide Use in Bangladesh. J. Health Pollut. 2018, 8, 181203. [CrossRef]

3. Alvarez, A.; Saez, J.M.; Davila Costa, J.S.; Colin, V.L.; Fuentes, M.S.; Cuozzo, S.A.; Benimeli, C.S.; Polti, M.A.; Amoroso, M.J. Actinobacteria: Current research and perspectives for bioremediation of pesticides and heavy metals. Chemosphere 2017, 166, 41-62. [CrossRef]

4. Skrbic, B.D.; Marinkovic, V. Occurrence, seasonal variety of organochlorine compounds in street dust of Novi Sad, Serbia, and its implication for risk assessment. Sci. Total Environ. 2019, 662, 895-902. [CrossRef] [PubMed]

5. Mansano, A.S.; Moreira, R.A.; Dornfeld, H.C.; Diniz, L.G.R.; Vieira, E.M.; Daam, M.A.; Rocha, O.; Seleghim, M.H.R. Acute and chronic toxicity of diuron and carbofuran to the neotropical cladoceran Ceriodaphnia silvestrii. Environ. Sci. Pollut. Res. Int. 2018, 25, 13335-13346. [CrossRef] [PubMed]

6. Onunga, D.O.; Kowino, I.O.; Ngigi, A.N.; Osogo, A.; Orata, F.; Getenga, Z.M.; Were, H. Biodegradation of carbofuran in soils within Nzoia River Basin, Kenya. J. Environ. Sci. Health B 2015, 50, 387-397. [CrossRef] [PubMed]

7. Wang, X.; Lu, L.; Yao, M.; Zhang, H.; Bao, J. Degradation of Carbofuran in Contaminated Soil by Immobilized Laccase. Polish J. Environ. Stud. 2017, 26, 1305-1312. [CrossRef]

8. Schafer, R.B.; Caquet, T.; Siimes, K.; Mueller, R.; Lagadic, L.; Liess, M. Effects of pesticides on community structure and ecosystem functions in agricultural streams of three biogeographical regions in Europe. Sci. Total Environ. 2007, 382, 272-285. [CrossRef]

9. Laocharoen, S.; Plangklang, P.; Reungsang, A. Selection of support materials for immobilization of Burkholderia cepacia PCL3 in treatment of carbofuran-contaminated water. Environ. Technol. 2013, 34, 2587-2597. [CrossRef]

10. Singh, D.K. Biodegradation and bioremediation of pesticide in soil: Concept, method and recent developments. Indian J. Microbiol. 2008, 48, 35-40. [CrossRef] 
11. Azubuike, C.C.; Chikere, C.B.; Okpokwasili, G.C. Bioremediation techniques-classification based on site of application: Principles, advantages, limitations and prospects. World J. Microbiol. Biotechnol. 2016, 32, 180. [CrossRef] [PubMed]

12. Li, R.; Dorfler, U.; Munch, J.C.; Schroll, R. Enhanced degradation of isoproturon in an agricultural soil by a Sphingomonas sp. strain and a microbial consortium. Chemosphere 2017, 168, 1169-1176. [CrossRef] [PubMed]

13. Tallur, P.N.; Mulla, S.I.; Megadi, V.B.; Talwar, M.P.; Ninnekar, H.Z. Biodegradation of cypermethrin by immobilized cells of Micrococcus sp. strain CPN 1. Braz. J. Microbiol. 2015, 46, 667-672. [CrossRef] [PubMed]

14. Morillo, E.; Villaverde, J. Advanced technologies for the remediation of pesticide-contaminated soils. Sci. Total Environ. 2017, 586, 576-597. [CrossRef]

15. Fareed, A.; Zaffar, H.; Rashid, A.; Maroof Shah, M.; Naqvi, T.A. Biodegradation of N-methylated carbamates by free and immobilized cells of newly isolated strain Enterobacter cloacae strain TA7. Bioremediat. J. 2017, 21, 119-127. [CrossRef]

16. Plangklang, P.; Reungsang, A.; Suphannafai, W. Bioremediation of carbofuran contaminated soil under saturated condition: Soil column study. Biodegradation 2012, 23, 473-485. [CrossRef]

17. Gao, Y.; Truong, Y.B.; Cacioli, P.; Butler, P.; Kyratzis, I.L. Bioremediation of pesticide contaminated water using an organophosphate degrading enzyme immobilized on nonwoven polyester textiles. Enzym. Microb. Technol. 2014, 54, 38-44. [CrossRef]

18. Alvarez-Martin, A.; Rodriguez-Cruz, M.S.; Andrades, M.S.; Sanchez-Martin, M.J. Application of a biosorbent to soil: A potential method for controlling water pollution by pesticides. Environ. Sci. Pollut. Res. Int. 2016, 23, 9192-9203. [CrossRef]

19. More, V.S.; Tallur, P.N.; Niyonzima, F.N.; More, S.S. Enhanced degradation of pendimethalin by immobilized cells of Bacillus lehensis XJU. 3 Biotech 2015, 5, 967-974. [CrossRef]

20. Abdel-Razek, M.A.; Folch-Mallol, J.L.; Perezgasga-Ciscomani, L.; Sanchez-Salinas, E.; Castrejon-Godinez, M.L.; Ortiz-Hernandez, M.L. Optimization of methyl parathion biodegradation and detoxification by cells in suspension or immobilized on tezontle expressing the opd gene. J. Environ. Sci. Health B 2013, 48, 449-461. [CrossRef]

21. Kadakol, J.C.; Kamanavalli, C.M.; Shouche, Y. Biodegradation of Carbofuran phenol by free and immobilized cells of Klebsiella pneumoniae ATCC13883T. World J. Microbiol. Biotechnol. 2011, 27, 25-29. [CrossRef]

22. Ibrahim, S.; Shukor, M.Y.; Syed, M.A.; Johari, W.L.; Shamaan, N.A.; Sabullah, M.K.; Ahmad, S.A. Enhanced caffeine degradation by immobilised cells of Leifsonia sp. strain SIU. J. Gen. Appl. Microbiol 2016, 62, 18-24. [CrossRef] [PubMed]

23. Chung, T.-P.; Tseng, H.-Y.; Juang, R.-S. Mass transfer effect and intermediate detection for phenol degradation in immobilized Pseudomonas putida systems. Process. Biochem. 2003, 38, 1497-1507. [CrossRef]

24. Ahmad, S.A.; Shamaan, N.A.; Arif, N.M.; Koon, G.B.; Shukor, M.Y.A.; Syed, M.A. Enhanced phenol degradation by immobilized Acinetobacter sp. strain AQ5NOL 1. World J. Microbiol. Biotechnol. 2012, 28, 347-352. [CrossRef]

25. Banerjee, A.; Ghoshal, A.K. Phenol degradation performance by isolated Bacillus cereus immobilized in alginate. Int. Biodeterior. Biodegrad. 2011, 65, 1052-1060. [CrossRef]

26. Prabu, C.S.; Thatheyus, A. Biodegradation of acrylamide employing free and immobilized cells of Pseudomonas aeruginosa. Int. Biodeterior. Biodegrad. 2007, 60, 69-73. [CrossRef]

27. Farag, S.; Soliman, N.A.; Abdel-Fattah, Y.R. Enhancement of crude oil biodegradation by immobilized bacterial consortium in small batch and continuous bioreactor Modes. Egypt. J. Chem. 2018, 61, 1019-1030. [CrossRef]

28. Gao, H.; Zhang, J.; Lai, H.; Xue, Q. Degradation of asphaltenes by two Pseudomonas aeruginosa strains and their effects on physicochemical properties of crude oil. Int. Biodeterior. Biodegrad. 2017, 122, 12-22. [CrossRef]

29. Vijayalakshmi, P.; Usha, M. Optimization of chlorpyrifos degradation by Pseudomonas putida. J. Chem. Pharm. Res. 2012, 4, 2532-2539.

30. Riaz ul, H.; Shakoori, A.R. Microorganisms resistant to heavy metals and toxic chemicals as indicators of environmental pollution and their use in bioremediation. Folia Biol. 2000, 48, 143-147.

31. Kamashwaran, S.R.; Crawford, D.L. Mechanisms of cadmium resistance in anaerobic bacterial enrichments degrading pentachlorophenol. Can. J. Microbiol. 2003, 49, 418-424. [CrossRef] [PubMed]

32. Sakkos, J.K.; Kieffer, D.P.; Mutlu, B.R.; Wackett, L.P.; Aksan, A. Engineering of a silica encapsulation platform for hydrocarbon degradation using Pseudomonas sp. NCIB 9816-4. Biotechnol. Bioeng. 2016, 113, 513-521. [CrossRef] [PubMed] 
33. Hong, H.-B.; Nam, I.-H.; Kim, Y.-M.; Chang, Y.-S.; Schmidt, S. Effect of heavy metals on the biodegradation of dibenzofuran in liquid medium. J. Hazard. Mater. 2007, 140, 145-148. [CrossRef] [PubMed]

34. Zhou, F.; Wang, H.; Fang, S.; Zhang, W.; Qiu, R. Pb(II), Cr(VI) and atrazine sorption behavior on sludge-derived biochar: Role of humic acids. Environ. Sci. Pollut Res. Int. 2015, 22, 16031-16039. [CrossRef]

35. Ibrahim, S.; Muhammad, A.; Tanko, A.S.; Abubakar, A.; Ibrahim, H.; Shukor, M.Y.; Ahmad, S.A. Studies of action of heavy metals on caffeine degradation by immobilised Leifsonia sp. strain SIU. Bayero J. Pure Appl. Sci. 2015, 8, 138-144. [CrossRef]

36. Liu, R.; Jiang, H.; Xu, P.; Qiao, C.; Zhou, Q.; Yang, C. Engineering chlorpyrifos-degrading Stenotrophomonas sp. YC-1 for heavy metal accumulation and enhanced chlorpyrifos degradation. Biodegradation 2014, 25, 903-910. [CrossRef]

37. Radjendirane, V.; Bhat, M.A.; Vaidyanathan, C. Affinity purification and characterization of 2, 4-dichlorophenol hydroxylase from Pseudomonas cepacia. Arch. Biochem. Biophys. 1991, 288, 169-176. [CrossRef]

38. Sokhn, J.; De Leij, F.; Hart, T.; Lynch, J. Effect of copper on the degradation of phenanthrene by soil micro-organisms. Lett. Appl. Microbiol. 2001, 33, 164-168. [CrossRef]

39. Niazi, J.H.; Karegoudar, T.B. Degradation of dimethylphthalate by cells of Bacillus sp. immobilized in calcium alginate and polyurethane foam. J. Environ. Sci. Health A Toxic Hazard. Subst. Environ. Eng. 2001, 36, 1135-1144. [CrossRef]

40. Sreenivasulu, C.; Aparna, Y. Bioremediation of methylparathion by free and immobilized cells of Bacillus sp. isolated from soil. Bull. Environ. Contam. Toxicol. 2001, 67, 98-105. [CrossRef]

41. Manohar, S.; Kim, C.; Karegoudar, T. Enhanced degradation of naphthalene by immobilization of Pseudomonas sp. strain NGK1 in polyurethane foam. Appl. Microbiol. Biotechnol. 2001, 55, 311-316. [CrossRef] [PubMed]

42. Liu, Y.; Zhang, A.; Wang, X. Biodegradation of phenol by using free and immobilized cells of Acinetobacter sp. XA05 and Sphingomonas sp. FG03. Biochem. Eng. J. 2009, 44, 187-192. [CrossRef]

43. Nie, M.; Nie, H.; He, M.; Lin, Y.; Wang, L.; Jin, P.; Zhang, S. Immobilization of biofilms of Pseudomonas aeruginosa NY3 and their application in the removal of hydrocarbons from highly concentrated oil-containing wastewater on the laboratory scale. J. Environ. Manag. 2016, 173, 34-40. [CrossRef]

44. Massalha, N.; Basheer, S.; Sabbah, I. Effect of adsorption and bead size of immobilized biomass on the rate of biodegradation of phenol at high concentration levels. Ind. Eng. Chem. Res. 2007, 46, 6820-6824. [CrossRef]

45. Krishna, K.R.; Philip, L. Biodegradation of lindane, methyl parathion and carbofuran by various enriched bacterial isolates. J. Environ. Sci. Health B 2008, 43, 157-171. [CrossRef]

46. Park, M.R.; Lee, S.; Han, T.; Oh, B.; Shim, J.H.; Kim, I.S. A new intermediate in the degradation of carbofuran by Sphingomonas sp. strain SB5. J. Microbiol. Biotechnol. 2006, 16, 1306.

47. Peng, X.; Zhang, J.S.; Li, Y.Y.; Li, W.; Xu, G.M.; Yan, Y.C. Biodegradation of insecticide carbofuran by Paracoccus sp. YM3. J. Environ. Sci. Health B 2008, 43, 588-594. [CrossRef]

48. Devatha, C.P.; Pavithra, N. Isolation and identification of Pseudomonas from wastewater, its immobilization in cellulose biopolymer and performance in degrading Triclosan. J. Environ. Manag. 2019, 232, 584-591. [CrossRef]

49. Velázquez-Fernández, J.B.; Martínez-Rizo, A.B.; Ramírez-Sandoval, M.; Domínguez-Ojeda, D. Biodegradation and Bioremediation of Organic Pesticides. In Pesticides-Recent Trends in Pesticide Residue Assay; InTech: London, UK, 2012.

50. Hakim, L.N.; Rochmadi; Sutijan. Phenol Biodegradation by Immobilized Pseudomonas Putida FNCC-0071 Cells in Alginate Beads; AIP Conference Proceedings; AIP Publishing: Melville, NY, USA, 2017; p. 050004.

51. Geng, Y.; Deng, Y.; Chen, F.; Jin, H.; Hou, T.; Tao, K. Isopropanol biodegradation by immobilized Paracoccus denitrificans in a three-phase fluidized bed reactor. Prep. Biochem. Biotechnol. 2016, 46, 747-754. [CrossRef]

52. Mustapha, M.U.; Halimoon, N.; Johari, W.L.W.; Shukor, M.Y.A. Characterization of Carbofuran-degrading Soil Bacteria. Science 2019, 1, 35-38.

53. Talwar, M.P.; Ninnekar, H.Z. Biodegradation of pesticide profenofos by the free and immobilized cells of Pseudoxanthomonas suwonensis strain HNM. J. Basic Microbiol. 2015, 55, 1094-1103. [CrossRef] [PubMed] 
54. Kumar, A.; Nain, L.; Singh, N. Alginate immobilized enrichment culture for atrazine degradation in soil and water system. J. Environ. Sci. Health B 2017, 52, 229-236. [CrossRef] [PubMed]

55. Sow, A.Y.; Ismail, A.; Zulkifli, S.Z. Geofractionation of heavy metals and application of indices for pollution prediction in paddy field soil of Tumpat, Malaysia. Environ. Sci. Pollut Res. Int. 2013, 20, 8964-8973. [CrossRef] [PubMed]

Sample Availability: Samples of the compounds are available.

(C) 2020 by the authors. Licensee MDPI, Basel, Switzerland. This article is an open access article distributed under the terms and conditions of the Creative Commons Attribution (CC BY) license (http://creativecommons.org/licenses/by/4.0/). 